\title{
Geochemical records in Neoproterozoic and young oils and early life conditions
}

\author{
ENVER ABLYA
}

MSU, Geology faculty, Leninskie gory, 1, Moscow, 119991, Russia, (eablya@yandex.ru )

Biomarker and isotopes records, microelements distribution from oils can show the evolving community of OM primary producers. We investigated this in Proterozoic Oldest oils from East Siberian and Russian plate basins and "youngest" oils from Uzon volcanic caldera is the largest geothermal field located in the eastern part of Kamchatka, Russia.

Half of Oldest oils and "youngest" oils shows traditional marine sources with C27, TA 26 compounds dominant in 2628 triaromatic and $\mathrm{C} 27-\mathrm{C} 29$ steranes and other aliphatic and terpanes HC's evidence as eukaryotic input contributions relative to bacterial biomass. But half Oldest oils and "youngest" oils shows "high plant" biomarkers type - S29, TA 28 compounds dominant, high tricyclic -tetracyclic terpanes / hopan H30 ratio. This oils shows some peculiarities - high content of 12-13 methyl isoprenoids, prevalence of C 32 and $C 35$ homo-hopanes, very light $\delta 13 \mathrm{C}$ values around 33- $-34 \%$ (but half "youngest" oils has more heavy $\delta 13 \mathrm{C}$ values around $-27--28 \%$ ) .

This half of Oldest oils content high concentration ( 30-50 ppm) of Arsenic and Lead. Uzon oils not content trace elements excluding a hundred ppm content of Arsenic [1]. Uzon oils -just generated by high algae with help\| of bacteria in boiling toxic geothermal solutions (with $\mathrm{pH}$ ofessentially zero, equivalent to a 1.2 molar concentration of sulfuric acid.) This bacterium are living in very extreme environments with high temperature and very high water acidity around. Part of oldest oils generated in same conditions from predominantly bacterium input. Extremophiles are believed to have been some of the earliest lifeforms on earth, since such early organisms would have to be adapted to harsh conditions.

[1] Ablya \& Labutova, (2009) Goldschmidt Conf. Abs., A4 